\title{
Augmented Natriuretic Response to Acute Sodium Infusion after Blood Pressure Elevation with Metaraminol in Normotensive Subjects *
}

\author{
Carlos A. Vaamonde, $†$ I. Norman Sporn, $\ddagger$ Ruben G. Lancestremere, $\S$ \\ Joseph L. Belsky, and Solomon Papper \\ (From the Medical Service and the Research Laboratory, Boston Veterans Administration \\ Hospital; the Departments of Medicine, Boston University and Tufts University \\ Schools of Medicine, Boston, Mass.; the Medical College of Virginia, \\ Richmond, Va.; the Department of Medicine, University of New \\ Mexico School of Medicine, and the Bernalillo County-Indian \\ Hospital, Albuquerque, N. Mex.)
}

That patients with essential hypertension have an exaggerated natriuretic response to the rapid intravenous administration of sodium is well established (1-5). Other hypertensive states have also been reported to exhibit an exaggerated natriuretic response to acute salt loading $(4,6-$ 11). Although the mechanisms responsible for this phenomenon remain unknown (5), one of the possibilities is that the elevation of the blood pressure per se may cause the enhanced natriuresis $(10)$.

In the present investigation the natriuretic response to acutely administered sodium was studied under controlled conditions in normotensive subjects and after elevation of the blood pressure with the pressor amine, metaraminol. Subjects excreted two to four times as much sodium as when responding to a similar sodium load without metaraminol.

* Submitted for publication September 12, 1963; accepted November 14, 1963.

Supported by research grants HE 5162 and $\mathrm{HE}$ 07665 from the National Heart Institute, U. S. Public Health Service.

Presented in part at the Fifty-fifth Annual Meeting of the American Society for Clinical Investigation, Atlantic City, N. J., April 29, 1963 (J. clin. Invest. 1963, 42, 988).

† Work done during the tenure of research fellowships of the University of Buenos Aires, Argentina, and the American Heart Association.

$\ddagger$ Postdoctoral research fellow of the National Heart Institute.

§ Work done during the tenure of a research fellowship of the American Heart Association and the Roanoke Valley Heart Association.

\section{Methods}

Five normotensive male subjects (three Caucasians and two Negroes), ages 33 to 48, without evidence of cardiac, hepatic, or renal disease were studied. Three had minimal healing dermatological lesions, one had inactive duodenal ulcer, and the other had minimal inactive pulmonary tuberculosis.

Three subjects (group I, no. 1, 2, and 3) received a total daily intake of $150 \mathrm{mEq}$ of sodium. They were provided a diet containing $10 \mathrm{mEq}$ of sodium daily and in addition were given $35 \mathrm{mEq}$ of sodium chloride in gelatin capsules with each meal and at bedtime. Two subjects (group II, no. 4 and 5 ) received a total daily sodium intake of $10 \mathrm{mEq}$. Daily urine excretion of sodium was determined, and the patients were in sodium balance at the time each of the following studies was performed. The particular chronological order in which these studies were done was varied among the subjects.

\section{Group I. Daily sodium intake of $150 \mathrm{mEq}$}

1) "Blank day." The subjects had breakfast and drank $20 \mathrm{ml}$ of tap water per $\mathrm{kg}$ of body weight between 7 and 8 a.m. At 8 a.m. the subjects lay down and remained recumbent until 3 p.m., except for standing to void at half-hour intervals. After each voiding they were given by mouth $5 \mathrm{~g}$ of carbohydrate and sufficient water to maintain a stable urine flow. Blood pressure and pulse were recorded at 30 -minute intervals. The sodium chloride capsules were omitted on the morning of each day of study. At 3 p.m., when the day's study was completed, the two omitted doses of salt were administered so that the daily total oral intake of sodium remained $150 \mathrm{mEq}$

2) "Metaraminol control day." The protocol was the same as on "blank day," except that 10 to $16 \mathrm{mg}$ of metaraminol (Aramine), ${ }^{1}$ dissolved in $5 \%$ dextrose in water, was given intravenously from 9:30 a.m. to 1 p.m. at a rate (average of $53 \mu \mathrm{g}$ per minute) adjusted to raise the mean blood pressure an average of $27 \mathrm{~mm} \mathrm{Hg}$

\footnotetext{
${ }^{1}$ Merck Sharp \& Dohme, Inc., Philadelphia, Pa.
} 
TABLE I

Sodium excretion in subjects provided a 150-mEq sodium diet

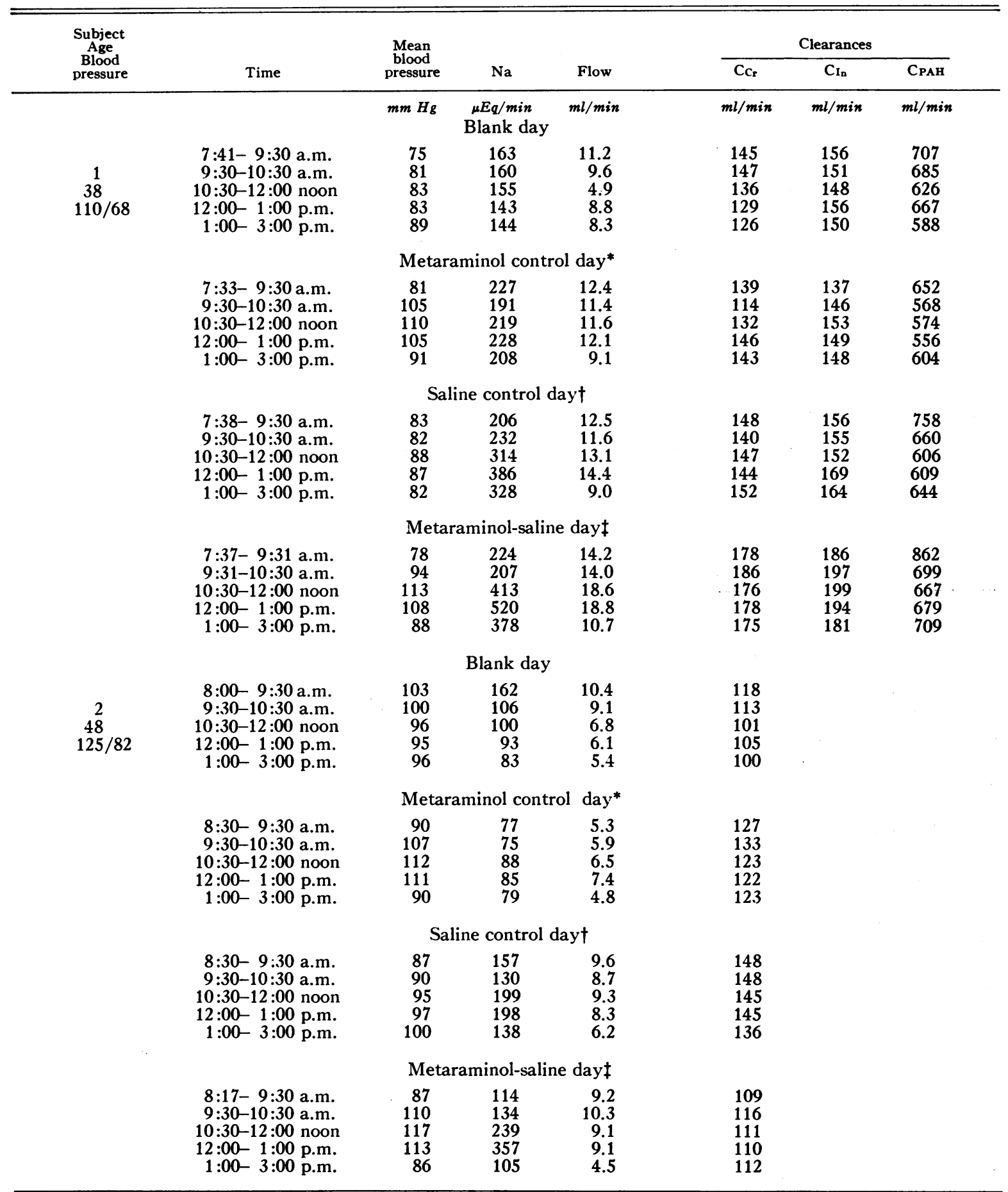

* Metaraminol was infused intravenously from 9:30 a.m. to 1:00 p.m.

$\dagger$ Two thousand $\mathrm{ml}$ of sodium chloride-lactate solution was infused intravenously from 10:30 a.m. to 12:00 noon. $\ddagger$ Metaraminol was infused intravenously from 9:30 a.m. to 1:00 p.m., and 2,000 ml of sodium chloride-lactate solution was administered intravenously from 10:30 a.m. to 12:00 noon. 
TABLE 1-(Continued $)$

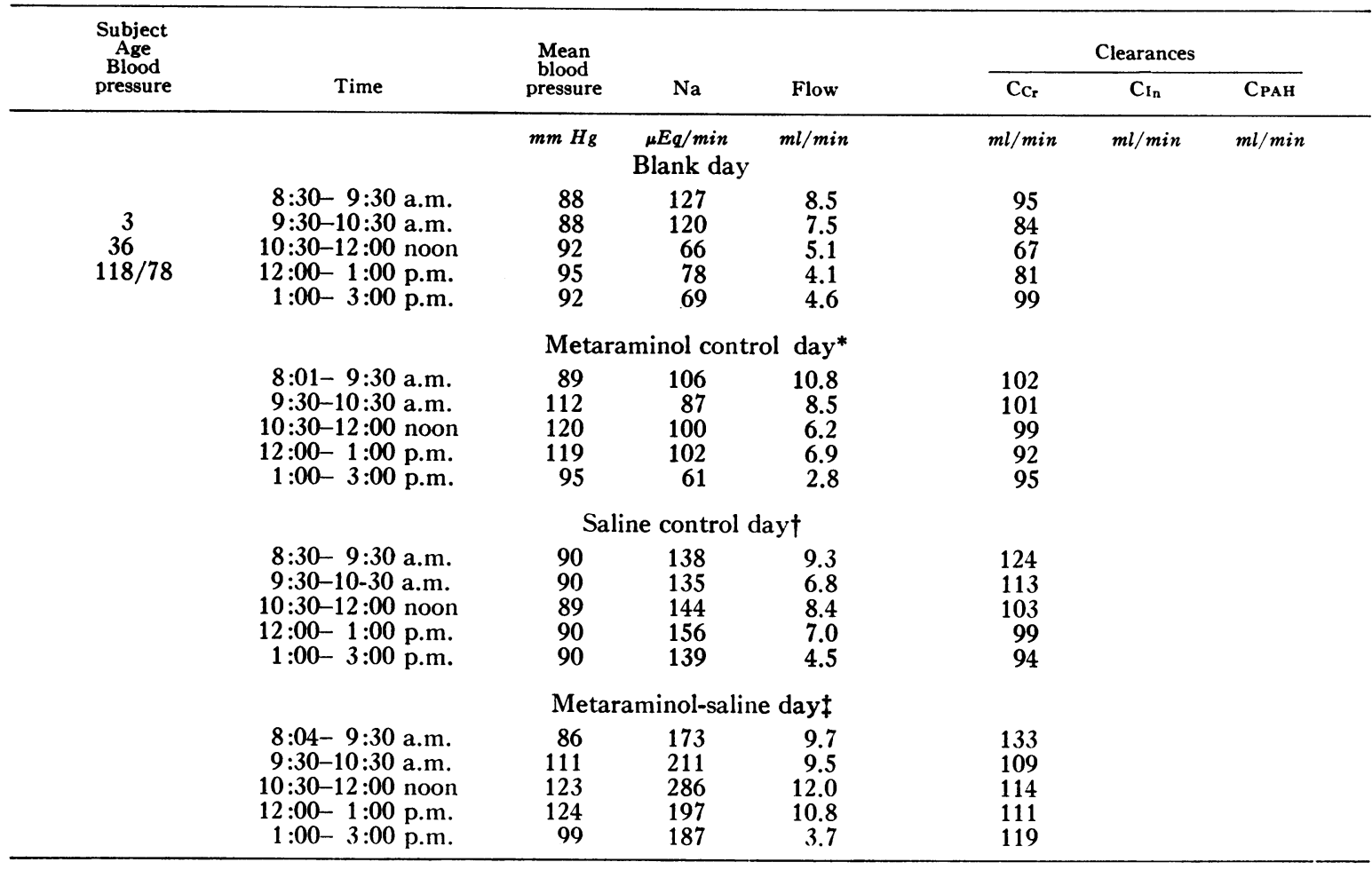

above the premetaraminol level. The blood pressure and pulse rate were recorded every 2 to 5 minutes. The mean blood pressure was calculated as the diastolic pressure plus one-third of the pulse pressure.

3) "Saline control day." The protocol was the same as on "blank day," except that $2,000 \mathrm{ml}$ of a solution containing $125 \mathrm{mEq}$ per $\mathrm{L}$ of sodium, $100 \mathrm{mEq}$ per $\mathrm{L}$ of chloride, and $25 \mathrm{mEq}$ per $\mathrm{L}$ of lactate was administered intravenously from 10:30 a.m. to 12 noon.

4) "Metaraminol-saline day." The protocol was the same as on "blank day," except that the metaraminol solution was infused between 9:30 a.m. and 1 p.m. as described for the "metaraminol control day" and that the hypotonic sodium solution was given from 10:30 a.m. to 12 noon as described for the "saline control day."

\section{Group II. Daily sodium intake of $10 \mathrm{mEq}$}

These two subjects were studied as described for "saline control day" and "metaraminol-saline day." The protocols were the same, except that the oral water load was $500 \mathrm{ml}$.

Creatinine, sodium, potassium, chloride, and total solutes were measured in serum and urine. Endogenous creatinine $\left(\mathrm{C}_{\mathrm{Cr}}\right)$, osmolal $\left(\mathrm{C}_{\mathrm{osm}}\right)$, and free water $\left(\mathrm{C}_{\mathrm{H}_{2} \mathrm{O}}\right)$ clearances were calculated in all subjects. Inulin and para-aminohippurate clearances $\left(\mathrm{C}_{\mathrm{In}}, \mathrm{C}_{\mathbf{P A H}_{\mathrm{A}}}\right)$ were estimated in Subject 1 throughout the studies by a standard technique (12) and without catheterization of the bladder. Sodium and potassium were measured with a Baird flame photometer with an internal lithium standard. The Aminco-Cotlove automatic chloride titrator was

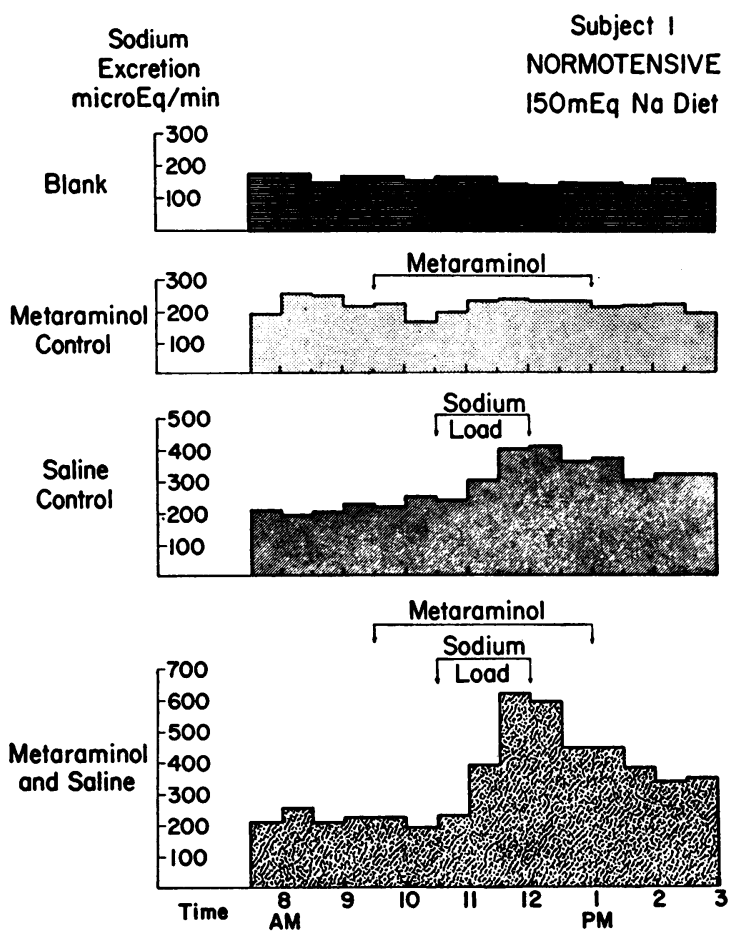

Fig. 1. Sodium excretion in ONe Subject (No. 1) ON "BLANK DAY," “METARAMinOL CONTROL DAY," "SAline CONTROL DAY," AND “METARAMinOl-SALINe DAY." Daily sodium intake, $150 \mathrm{mEq}$. 
used to measure chloride. Creatinine was determined in urine by the method of Peters (13) and in serum by the technique of Hare (14). Inulin was measured by the anthrone procedure of Young and Raisz (15). Para-aminohippurate was determined by the method of Goldring and Chasis (16). The Fiske osmometer was employed to measure concentration of total solutes.

\section{Results}

1) "Blank day." The average mean blood pressure for group I was $90 \mathrm{~mm} \mathrm{Hg} . \mathrm{C}_{\mathrm{Cr}}, \mathrm{C}_{\mathrm{In}}$, and $\mathrm{C}_{\mathbf{P A H}}$ were within the normal range, except for Subject 3, who on this day had a moderately low $\mathrm{C}_{\mathrm{Cr}}$ (Table I).

2) "Metaraminol control day." During metaraminol infusion the average mean blood pressure for group I was $111 \mathrm{~mm} \mathrm{Hg}$. The rate of excretion of sodium was unaltered (Table I, Figure 1). There was no difference in the maximal increase of sodium excretion from the mean preinfusion rate between the "metaraminol control day" and the "blank day" (Table III, Figure 2). Neither
$\mathrm{C}_{\mathrm{Cr}}$ nor $\mathrm{C}_{\mathrm{In}}$ changed significantly (more than 15\%) (Table I).

3) "Saline control day." After the sodium infusion there was no change in mean blood pressure. The rate of excretion of sodium increased in the five subjects studied (Tables I, II, and III; Figures 1 and 2).

In four of the five subjects, during the saline administration neither $\mathrm{C}_{\mathrm{Cr}}$ nor $\mathrm{C}_{\text {In }}$ was significantly different from the preinfusion periods ( $\mathrm{Ta}$ bles I and II). Subject 3 had a slight decrease in $\mathrm{C}_{\mathrm{Cr}}$. Subject 1 had a $16 \%$ decrease in $\mathrm{C}_{\mathbf{P A H}}$. After the salt load there were no significant changes in the serum concentration of sodium ( -0.4 to $+3 \mathrm{mEq}$ per $\mathrm{L})$, chloride $(-3.2$ to $+3.9 \mathrm{mEq}$ per $\mathrm{L})$, or potassium $(-0.3$ to +0.2 $\mathrm{mEq}$ per L).

4) "Metaraminol-saline day." The average mean blood pressure during the metaraminol and saline infusions was $112 \mathrm{~mm} \mathrm{Hg}$. The excretion of sodium increased in all the subjects (Tables I,

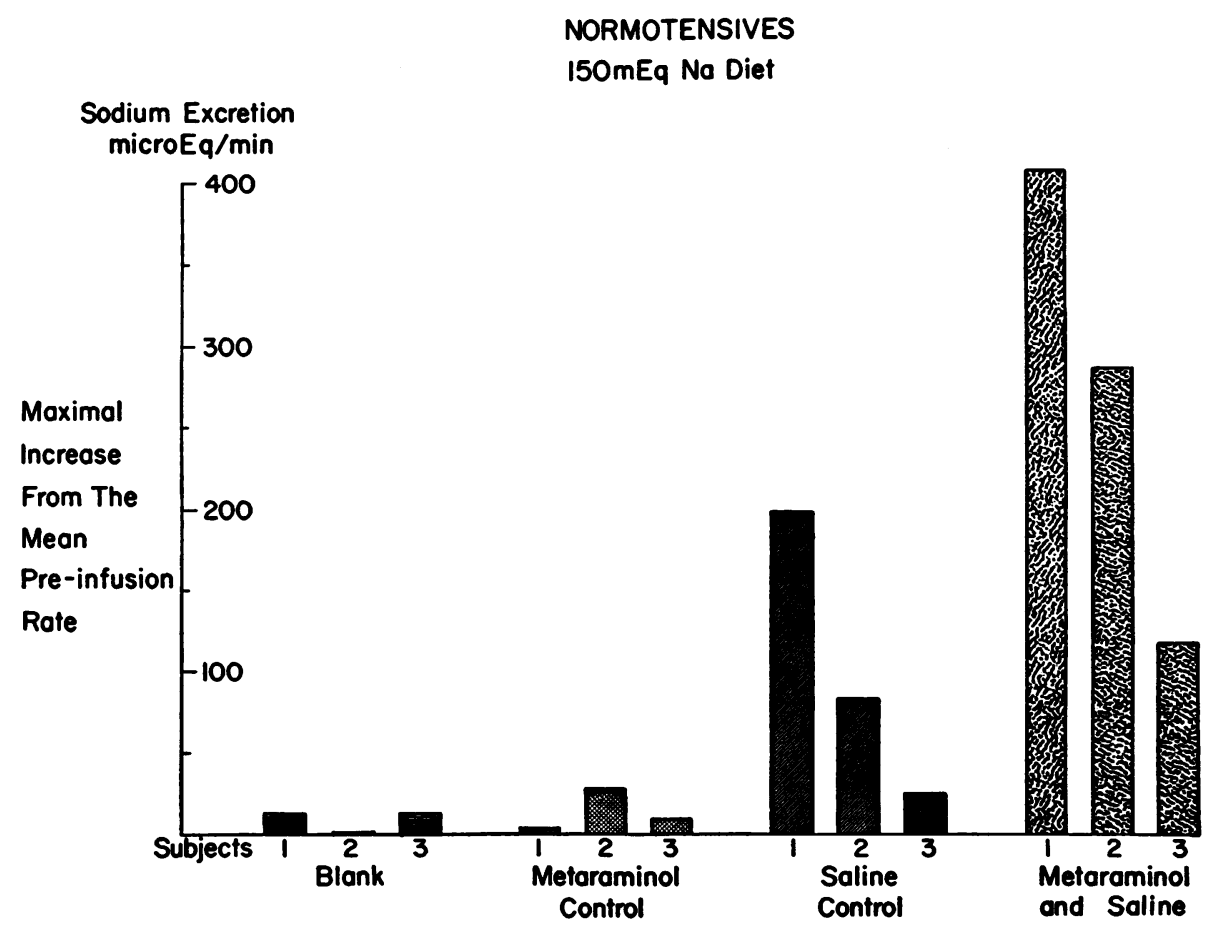

Fig. 2. Sodium excretion in three subjects (Nos. 1, 2, 3) on "blank day,"

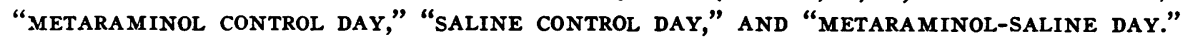
Daily sodium intake, $150 \mathrm{mEq}$. The maximal increase of sodium excretion (from 9:30 a.m. to 3 p.m.) from the mean preinfusion rate $(8: 30$ to $9: 30$ a.m.) in microequivalents per minute (peak rate minus preinfusion rate) is on the vertical scale. Each column represents an individual subject studied on the 4 experimental days. (On "blank day," Subject 2 had the highest rate of sodium excretion before 9:30 a.m.) 
TABLE II

Sodium excretion in subjects provided a 10-mEq sodium diet

\begin{tabular}{|c|c|c|c|c|c|}
\hline $\begin{array}{c}\text { Subject } \\
\text { Age } \\
\text { Blood } \\
\text { pressure }\end{array}$ & Time & $\begin{array}{c}\text { Mean } \\
\text { blood } \\
\text { pressure }\end{array}$ & $\mathrm{Na}$ & Flow & $\mathrm{C}_{\mathrm{Cr}}$ \\
\hline & & $m m H g$ & $\underset{\min }{\mu E q /}$ & $\min ^{m l /}$ & $\begin{array}{l}\text { min } \\
\text { min }\end{array}$ \\
\hline \multicolumn{6}{|c|}{ Saline control day* } \\
\hline & $8: 00-9: 30$ a.m. & 84 & 16 & 2.8 & 163 \\
\hline 4 & $9: 30-10: 30$ a.m. & 84 & 19 & 1.5 & 148 \\
\hline 38 & $10: 30-12: 00$ noon & 87 & 122 & 9.8 & 144 \\
\hline \multirow[t]{2}{*}{$118 / 70$} & $12: 00-1: 00$ p.m. & 86 & 174 & 4.3 & 143 \\
\hline & $1: 00-3: 00$ p.m. & 80 & 190 & 2.6 & 153 \\
\hline \multicolumn{6}{|c|}{ Metaraminol-saline day $\dagger$} \\
\hline & $8: 00-9: 30$ a.m. & 84 & 44 & 1.1 & 152 \\
\hline & 9:30-10:30 a.m. & 102 & 46 & 3.7 & 144 \\
\hline & $10: 30-12: 01$ p.m. & 110 & 745 & 13.5 & 141 \\
\hline & $12: 01-1: 00$ p.m. & 114 & 1,429 & 15.9 & 147 \\
\hline & $1: 00-3: 00$ p.m. & 82 & 326 & 2.6 & 131 \\
\hline \multicolumn{6}{|c|}{ Saline control day* } \\
\hline & $8: 00-9: 30$ a.m. & 74 & 25 & 7.9 & 130 \\
\hline 5 & $9: 30-10: 30$ a.m. & 73 & 34 & 12.2 & 120 \\
\hline 33 & $10: 30-12: 00$ noon & 73 & 56 & 8.7 & 117 \\
\hline \multirow[t]{8}{*}{$110 / 64$} & $12: 00-1: 00$ p.m. & 78 & 130 & 5.6 & 118 \\
\hline & $1: 00-3: 00$ p.m. & 74 & 176 & 8.1 & 123 \\
\hline & \multicolumn{4}{|c|}{ Metaraminol-saline day $\dagger$} & \\
\hline & $8: 00-9: 30$ a.m. & 80 & 15 & 8.3 & 103 \\
\hline & $9: 30-10: 30$ a.m. & 96 & 13 & 10.3 & 107 \\
\hline & $10: 30-12: 00$ noon & 119 & 95 & 8.7 & 112 \\
\hline & 12:00- $1: 00$ p.m. & 117 & 263 & 6.5 & 114 \\
\hline & $1: 00-2.41$ p.m. & 88 & 159 & 5.1 & 114 \\
\hline
\end{tabular}

* Two thousand $\mathrm{ml}$ of sodium chloride-lactate solution was infused intravenously from 10:30 a.m. to $12: 00$ noon.

$\dagger$ Metaraminol was infused intravenously from 9:30 a.m. to 1:00 p.m., and $2,000 \mathrm{ml}$ of sodium chloride-lactate solution was administered intravenously from 10:30 a.m. to $12: 00$ noon.

II, and III). The maximal increase of sodium excretion from the mean preinfusion rate on this day was an average of $261 \%$ greater than on the "saline control day" in the three subjects of group I (Figure 2). ${ }^{2}$

Similar results were obtained in the two subjects studied while taking the $10-\mathrm{mEq}$ sodium diet. Figure 3 illustrates the results in one of these subjects.

There were no significant changes in $\mathrm{C}_{\mathrm{Cr}}$ or $\mathrm{C}_{\text {In }}$ after the metaraminol and saline infusions in four of the five subjects (Tables I and II). Subject 3 had a slight decrease in $\mathrm{C}_{\mathrm{Cr}}$. In Subject 1 the $\mathrm{C}_{\mathrm{PAH}}$ decreased $21 \%$ after the vasopressor infusion.

2 Angiotensin II was employed in Subject 1 with different results. The excretion of sodium after the administration of angiotensin II was markedly reduced, as described by others (17-20). This effect of angiotensin II on sodium excretion was not markedly modified by the rapid iv administration of sodium.

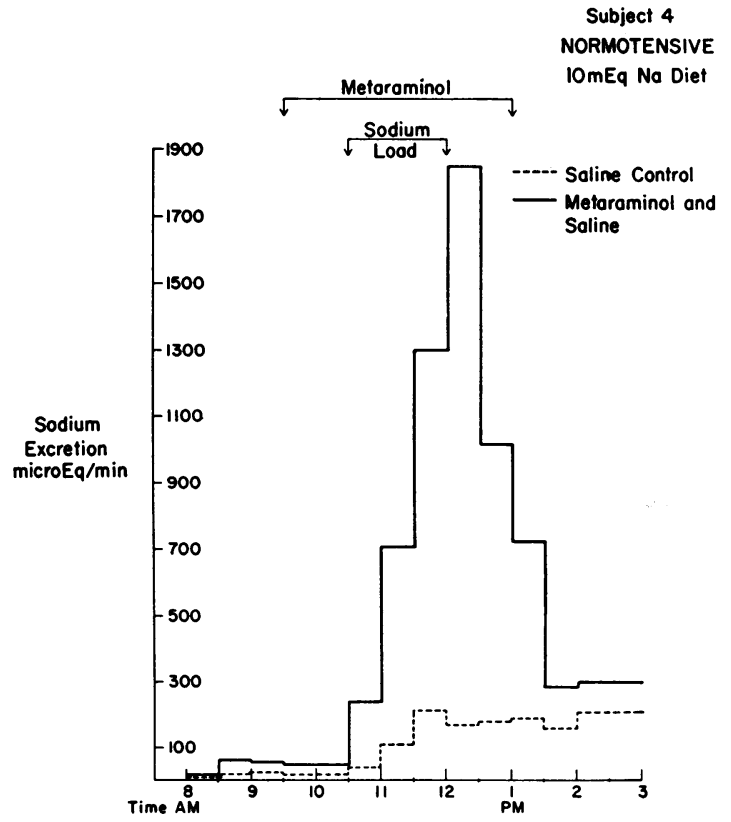

Fig. 3. Sodium excretion in one subject (No. 4) on "SAline CONTRol Day" AND "Metaraminol-SAline DAY." Daily sodium intake, $10 \mathrm{mEq}$.

TABLE III

Sodium excretion in normotensive subjects after blood pressure elevation with metaraminol

\begin{tabular}{|c|c|c|c|c|}
\hline \multirow[b]{2}{*}{ Subject } & \multirow[b]{2}{*}{ Experimental day } & \multicolumn{3}{|c|}{ Rate of sodium excretion } \\
\hline & & $\begin{array}{l}\text { Prein- } \\
\text { fusion* }\end{array}$ & Peak† & $\begin{array}{l}\text { Peak - } \\
\text { prein- } \\
\text { fusiont }\end{array}$ \\
\hline \multirow{5}{*}{1} & & $\underset{\min }{\mu E_{q}^{\prime}}$ & $\underset{\min }{\mu E q /}$ & $\underset{\min }{\mu E q^{\prime}}$ \\
\hline & Blank & 154 & 166 & 12 \\
\hline & Metaraminol control & 232 & 236 & 4 \\
\hline & Saline control & 213 & 410 & 197 \\
\hline & Metaraminol-saline & 216 & 620 & 404 \\
\hline \multirow{4}{*}{2} & Blank & 153 & 121 & $-32 \S$ \\
\hline & Metaraminol control & 77 & 104 & 27 \\
\hline & Saline control & 157 & 239 & 82 \\
\hline & Metaraminol-saline & 90 & 374 & 284 \\
\hline \multirow{4}{*}{3} & Blank & 127 & 139 & 12 \\
\hline & Metaraminol control & 103 & 113 & 10 \\
\hline & Saline control & 138 & 162 & 24 \\
\hline & Metaraminol-saline & 187 & 315 & 128 \\
\hline \multirow{2}{*}{4} & Saline control & 21 & 212 & 191 \\
\hline & Metaraminol-saline & 58 & 1,842 & 1,784 \\
\hline \multirow{2}{*}{5} & Saline control & 34 & 194 & 160 \\
\hline & Metaraminol-saline & 23 & 323 & 300 \\
\hline
\end{tabular}

* Mean rate of sodium excretion from 8:30 to 9:30 a.m.

$\dagger$ Maximal 30-minute period of sodium excretion from 9:30 a.m. to $3: 00$ p.m.

$\ddagger$ Maximal increase in sodium excretion from the mean preinfusion rate.

$\$$ On "blank day," Subject 2 had the highest rate of sodium excretion before $9: 30 \mathrm{a} . \mathrm{m}$. 
During the saline infusion serum sodium concentration did not change significantly in four of the subjects ( -0.1 to $+4.4 \mathrm{mEq}$ per $\mathrm{L})$ and decreased $9.6 \mathrm{mEq}$ per $\mathrm{L}$ in Subject 3. There were no significant changes in serum potassium concentration in four subjects $(-0.6$ to $+0.2 \mathrm{mEq}$ per L) and a decrease of $0.9 \mathrm{mEq}$ per $\mathrm{L}$ in Subject 1 . There were no significant changes in serum chloride concentration $(-1.4$ to $+3.8 \mathrm{mEq}$ per L).

The excretion of chloride and total solutes and urine flow generally followed the changes in sodium excretion in all the experimental days. There were no remarkable changes in the rate of excretion of potassium, except for a transient increase with the saline infusion in group II. The $\mathrm{C}_{\text {osm }}$ increased on the "metaraminol-saline day." There were no consistent changes in $\mathrm{C}_{\mathrm{osm}}$ or $\mathrm{C}_{\mathrm{H}_{2} \mathrm{O}}$ in the other experimental days. The pulse rate decreased in all the subjects during the metaraminol infusion; Subject 2 had few isolated premature beats.

\section{Discussion}

The administration of metaraminol in amounts sufficient to elevate systemic blood pressure in normotensive subjects is evidently accompanied by an enhanced natriuretic response to rapidly administered sodium. The augmented natriuresis observed is modest in comparison to the markedly enhanced natriuresis observed in patients with essential hypertension $(2,5)$. Although this difference might be related to differences in the degree of hypertension or the duration of increased blood pressure, the present data do not permit further interpretation of this point.

Although the possibility of a direct effect of the vasopressor agent on sodium excretion cannot be excluded, it seems unlikely, considering that the administration of, metaraminol alone did not result in increased sodium excretion. No significant changes in $\mathrm{C}_{\mathrm{Cr}}$ or $\mathrm{C}_{\text {In }}$ were observed in this study.

This augmented sodium excretion was present at two different levels of salt intake, 10 and 150 $\mathrm{mEq}$ of sodium daily. Papper, Belsky, and Bleifer (5) demonstrated that the exaggerated natriuresis of patients with essential hypertension is apparent at all levels of salt intake ranging from 10 to $300 \mathrm{mEq}$ daily.
There are observations implicating elevated blood pressure in the exaggerated natriuresis of hypertension. This phenomenon has been repeatedly reported in patients with essential hypertension (1-5). Patients with hypertension caused by chronic glomerulonephritis $(9,10)$, Cushing's syndrome $(4,6,7)$, pheochromocytoma (4), primary aldosteronism $(8,11)$, and unilateral renal disease (10) have also been reported to have an exaggerated natriuretic response to acute salt loading, suggesting that elevated blood pressure could be a common denominator in this phenomenon.

Selkurt, Hall, and Spencer (21) and more recently Tobian, Coffee, Ferreira, and Meuli (22) reported studies in animals indicating that an increase in renal arterial perfusion pressure results in augmented sodium excretion. The mechanisms whereby this occurred were not clear. Tobian and his associates suggested the possibility of some intrarenal humoral mediation, and Selkurt and co-workers considered some intrarenal hemodynamic alterations.

The present data do not permit further delineation of the precise mechanisms involved in the enhanced natriuresis observed when a salt load is administered after systemic blood pressure has been elevated with metaraminol in normotensive subjects.

\section{Summary}

The natriuretic response to an acutely administered intravenous sodium solution $(125 \mathrm{mEq}$ per L) was studied under controlled conditions in five normotensive subjects and after elevation of the blood pressure with the pressor amine, metaraminol.

Under the described conditions, there was an augmented natriuretic response to the rapid administration of sodium in the five normotensive subjects. This augmented response was present at two different levels of dietary sodium intake. The vasopressor agent alone did not increase sodium excretion.

The mechanisms whereby this enhanced natriuresis occurs in normotensive subjects under the described conditions are not known. 


\section{Acknowledgments}

The authors gratefully acknowledge the invaluable assistance of Mmes. Margie P. Homer, Joyce K. Randolph, and Loumella J. Faust.

\section{References}

1. Cottier, P. T., J. M. Weller, and S. W. Hoobler. Effect of an intravenous sodium chloride load on renal hemodynamics and electrolyte excretion in essential hypertension. Circulation 1958, 17, 750.

2. Baldwin, D. S., A. W. Biggs, W. Goldring, W. H. Hulet, and $H$. Chasis. Exaggerated natriuresis in essential hypertension. Amer. J. Med. 1958, 24, 893.

3. Cottier, P. T., J. M. Weller, and S. W. Hoobler. Sodium chloride excretion following salt loading in hypertensive subjects. Circulation 1958, 18, 196.

4. Hanenson, I. B., H. H. Taussky, N. Polasky, W. Ransohoff, and B. F. Miller. Renal excretion of sodium in arterial hypertension. Circulation 1959, 20, 498.

5. Papper, S., J. L. Belsky, and K. H. Bleifer. The response to the administration of an isotonic sodium chloride-lactate solution in patients with essential hypertension. J. clin. Invest. 1960, 39, 876.

6. Kriss, J. P., and P. H. Futcher. Renal excretion and tubular reabsorption of salt in Cushing's syndrome after intravenous administration of hypertonic sodium chloride. J. clin. Endocr. 1949, 9, 13.

7. Birchall, R., S. W. Tuthill, W. S. Jacobs, W. J. Trautman, Jr., and T. Findley. Renal excretion of water, sodium and chloride. Comparison of the responses of hypertensive patients with those of normal subjects, patients with specific adrenal or pituitary defects, and a normal subject primed with various hormones. Circulation 1953, 7, 258.

8. Ortúzar, R., R. Croxatto, P. Thomsen, and J. González. Effects of an acute salt load in a case of primary hyperaldosteronism before and nine months after surgical cure. J. Lab. clin. Med. 1959, 54, 712.

9. Sasamori, C. Effect of salt loading on renal hemodynamics and electrolytes excretion in essential hypertension and in chronic glomerulonephritis. Tohoku J. exp. Med. 1960, 71, 311.

10. Cottier, P. T. Renal hemodynamics, water and electrolyte excretion in essential hypertension in
Essential Hypertension. An International Symposium, K. D. Bock and P. T. Cottier, Eds. Berlin, Springer, 1960, p. 66.

11. Biglieri, E. G., and P. H. Forsham. Studies on the expanded extracellular fluid and the responses to various stimuli in primary aldosteronism. Amer. J. Med. 1961, 30, 564

12. Smith, H. W. Principles of Renal Physiology. New York, Oxford University Press, 1956, p. 196.

13. Peters, J. H. The determination of creatinine and creatine in blood and urine with the photoelectric colorimeter. J. biol. Chem. 1942, 146, 179.

14. Hare, R. S. Endogenous creatinine in serum and urine. Proc. Soc. exp. Biol. (N. Y.) 1950, 74, 148.

15. Young, M. K., Jr., and L. G. Raisz. An anthrone procedure for determination of inulin in biological fluids. Proc. Soc. exp. Biol. (N. Y.) 1952, 80, 771.

16. Goldring, W., and H. Chasis. Hypertension and Hypertensive Disease. New York, Commonwealth Fund, 1944, p. 203.

17. Bock, K. D., H. Dengler, H. J. Krecke, and G. Reichel. Untersuchungen über die Wirkung von synthetischem Hypertensin II auf Elektrolythaushalt, Nierenfunktion und Kreislauf beim Menschen. Klin. Wschr. 1958, 36, 808.

18. Peart, W. S. Hypertension and the kidney. II. Experimental basis of renal hypertension. Brit. med. J. 1959, 2, 1421.

19. McQueen, E. G., and R. B. I. Morrison. The effects of synthetic angiotensin and noradrenaline on blood pressure and renal function. Brit. Heart J. 1961, 23, 1 .

20. Biron, P., E. Koiw, W. Nowaczynski, J. Brouillet, and $J$. Genest. The effects of intravenous infusions of valine-5 angiotensin II and other pressor agents on urinary electrolytes and corticosteroids, including aldosterone. J. clin. Invest. 1961, 40, 338.

21. Selkurt, E. E., P. W. Hall, and M. P. Spencer. Influence of graded arterial pressure decrement on clearance of creatinine, $p$-aminohippurate and sodium. Amer. J. Physiol. 1949, 159, 369.

22. Tobian, L., K. Coffee, D. Ferreira, and J. Meuli. The effect of renal perfusion pressure on the net transport of sodium out of distal tubular urine as studied with the stop-flow technique. J. clin. Invest. 1964, 43, 118. 